\title{
Effect of Irrigation and Mulch on the Yield and Water Use of Strawberry
}

\author{
Rahena Parvin Rannu (D, ${ }^{1}$ Razu Ahmed, ${ }^{1}$ Alamgir Siddiky, ${ }^{1}$ Abu Saleh Md. Yousuf Ali, \\ Khandakar Faisal Ibn Murad, ${ }^{3}$ and Pijush Kanti Sarkar ${ }^{3}$ \\ ${ }^{1}$ Soil \& Water Management Section, Horticulture Research Centre, Bangladesh Agricultural Research Institute (BARI), \\ Gazipur 1701, Bangladesh \\ ${ }^{2}$ Regional Agricultural Research Station, Bangladesh Agricultural Research Institute (BARI), Gazipur 1701, Bangladesh \\ ${ }^{3}$ Irrigation \& Water Management Division, Bangladesh Agricultural Research Institute (BARI), Gazipur 1701, Bangladesh
}

Correspondence should be addressed to Rahena Parvin Rannu; rannu_bau@yahoo.com

Received 28 December 2017; Revised 12 March 2018; Accepted 15 March 2018; Published 22 May 2018

Academic Editor: Othmane Merah

Copyright (C) 2018 Rahena Parvin Rannu et al. This is an open access article distributed under the Creative Commons Attribution License, which permits unrestricted use, distribution, and reproduction in any medium, provided the original work is properly cited.

\begin{abstract}
To investigate the effect of irrigation and mulch on the yield of strawberry (line FA-007), this study was conducted at the experimental fields of Pomology Division, BARI, Gazipur and RARS, BARI, Rangpur during Rabi season of 2012-13 and 2013-14. The experiment was conducted followed by the split-plot design with two mulches (black plastic and rice straw), three levels of irrigation $(5,10$, and 15 days interval), and three replications. A significant difference was observed for most of the parameters among different treatments for both locations. Irrigation at 5 days interval with rice straw mulch in Gazipur and irrigation at 5 days interval with black polythene mulch in Rangpur were performed better for most of the yield-contributing characters and yield among all other treatments for both the years. But in respect to water productivity, 10 days irrigation interval with rice straw mulch in Gazipur and 10 days interval with black polythene mulch in Rangpur showed highest results among all other treatments. However, it can be concluded that any irrigation practices from the abovementioned options could be adopted by the farmers based on their feasibility and water availability for strawberry cultivation in Bangladesh.
\end{abstract}

\section{Introduction}

Strawberry (Fragaria $\times$ annanasa Dutch.) is one of the most popular fruits in the world. Besides their popularity as fresh fruits, strawberries are used to produce different food products. It is an excellent source of vitamin $\mathrm{C}, \beta$-carotene, dietary fiber, and some other nutrients for human health and nutrition [1]. It has been recently introduced in Bangladesh, and day by day, it is becoming very popular. The most important thing is that just few years before it was not only impossible for people to taste strawberry but also unpredictable for them to cultivate in their land or in home garden. But it became true, and now a lot of farmers and villagers have taken up the activity to grow strawberry. Strawberry cultivation has already gained much popularity among the farmers in Rangpur, Thakurgaon, Dinajpur,
Nilphamari, Gaibandha, Lalmonirhat, Kurigram, Panchagarh, Joypurhat, Naogaon, and other northern districts in Bangladesh [2]. There is no current statistical information regarding strawberry-cultivated area and production in Bangladesh. However, Monda [1] reported that 25000 tonnes of strawberry had been produced in 2009. According to Bangladesh Strawberry Association, around 6,500 bighas of land had been brought under strawberry cultivation throughout the country during the year of 2015-2016 where Rajshahi district is ahead of other districts for strawberry cultivation [3]. The northern region of Bangladesh may be suitable for strawberry cultivation for its relatively cool weather compared to other parts of Bangladesh. The crop is grown in Bangladesh during winter when there is low precipitation and high evapotranspiration. Crop cultivation during this dry period usually requires irrigation. Strawberry 
is relatively a shallow-rooted plant and susceptible to the water stress condition. Water stress may affect the photosynthetic activity and reduce the potential growth of the plant [4], and Kirnak et al. found that it caused reduction of fruit yield, fruit size, leaf nutrient compositions, and normal plant growth parameters in strawberry except water-soluble dry matter concentrations in fruits [5]. Limited soil moisture affects growth, development, yield, and existence of the strawberry plant in the winter season [6]. Irrigation plays an important role on the total yield, berry weight, runner production, and leaf area of strawberry [7].

So, frequent irrigation is necessary at different stages of strawberry plants. Water unavailability can affect all physiological processes of plant ultimately that has effect on mortality of plant [8]. Yield losses up to 60 to $100 \%$ are reported due to long spell of drought stress in different crop species [9]. Some fertilizers and pesticides may be applied through the irrigation system, thus reducing the need and cost to enter the field with equipment. Existing water resources either surface water or groundwater is at risk of near depletion, pollution, and being heavily degraded. There is also strong evidence for the possibility of decreasing rainfall year by year due to climate change [10]. So, it is the high time to develop efficient irrigation management techniques that can minimize water use or maximize the water use efficiency. Increasing water shortage worldwide has led irrigation scheduling to achieve an optimum water supply for productivity [11].

To minimize water use, strawberry planting must be mulched in the fall for good winter survival and maximum yields. Mulch plays an important role to regulate soil temperature, conserve moisture, restrict evaporation losses, and suppress weed growth, reducing the number of dirty and diseased berries [12, 13], enhancing nutrient uptake, and improving water use efficiency and yield [14]. The mulching technique increases the vegetative growth, flowering of plants, yield, and quality of strawberry [15] and creates loose soil surface that increases the total intake of water and reduces surface runoff [16]. Kirnak et al. [5] found that mulching can mitigate negative effects of water stress on the plant growth and fruit yield of strawberry under the fieldgrown condition especially in semiarid regions. Root zone temperatures play an important role in plant growth and development through the uptake of water and nutrients by roots. Pandey et al. [17] found beneficial effects of mulching on root zone temperature which were reflected in an increased number of fruits and fruit size. He recommended mulch for effective root zone temperature, weed control, and moisture regulation to grow strawberry. In spite of the inorganic plastic mulches (transparent, black or yellow, and others), other types of organic mulches are also used in field conditions in some parts of the world (wheat and rice straw, forest leaf, etc.). Normally, the locally available mulch is rice straw in Bangladesh. In the recent years, plastic mulches are also used for crop production. Organic mulches support diversity of beneficial soil macroinvertebrates in the soil [16] and reduce disease levels in the field plots [18]. On the other hand, black plastic mulch is used to warm the soil early [19] in the soil which ensures faster growth and development of plants. Bakshi et al. found that black polythene mulch also showed significant superiority in reducing weed population over other mulching treatments [20].

However, the information on the judicious use of irrigation water to different mulch materials on strawberry production is scanty in Bangladesh. Therefore, this study was undertaken to investigate the response of strawberry to irrigation and different mulch and to determine an appropriate irrigation schedule for strawberry production, in the agroenvironmental conditions of Bangladesh and similar areas of cultivation.

\section{Materials and Methods}

2.1. Experimental Site. The experiment was carried out during two successive growth seasons of 2012-13 and 2013-14, at two locations: (1) Horticulture Research Centre (HRC), Joydebpur, Gazipur which is located at $34 \mathrm{~m}$ altitude, 23.98 N latitude, and 90.42 E longitude and (2) Regional Agricultural Research Station (RARS), Burirhat, Rangpur which is at $11 \mathrm{~m}$ altitude, $25.82 \mathrm{~N}$ latitude, and $89.23 \mathrm{E}$ longitude. Both locations are under Bangladesh Agricultural Research Institute (BARI). Between these two locations, RARS, Burirhat, Rangpur location contains more coldness in winter than HRC, Joydebpur, Gazipur location due to geographical features. The average temperature and annual rainfall are $25.8^{\circ} \mathrm{C}$ and $2036 \mathrm{~mm}$, respectively, for Gazipur, whereas they are $24.9^{\circ} \mathrm{C}$ and $2192 \mathrm{~mm}$ for Rangpur. In Bangladesh, Rangpur is located at the north western part that is faced with prolonged dry season than the rest of the country [21]. For this study, temperature and rainfall data for the entire crop growing season of both locations were recorded (Table 1).

\subsection{Treatments and Experimental Design. The treatments} were as follows:

Factor A (main plot): $M_{1}=$ black polythene and $M_{2}=$ rice straw.

Factor B (subplot): $I_{1}=$ irrigation at 5 days interval after plant establishment (PE), $I_{2}=$ irrigation at 10 days interval after $\mathrm{PE}$, and $I_{3}=$ irrigation at 15 days interval after PE.

The experiment was laid out in a split-plot design (SPD) with three replications.

2.3. Planting Materials and Cultural Practices. The Strawberry line FA-007 was used as the test crop because BARI released varieties that were not available enough on that time. FA-007 was a promising line on that time under the supervision of relevant scientists which is released later as a variety (BARI Strawberry-03).

The texture of soil was loamy having a bulk density of $1.40 \mathrm{~g} / \mathrm{cc}$. The water content at the wilting point (WP) and field capacity (FC) were $14 \%$ and $29 \%$, respectively. Seedlings were transplanted in the first and last weeks of November in the two consecutive years at the age of 1 month of plant on raised bed. The unit plot size and spacing were $2.5 \mathrm{~m} \times 1.0 \mathrm{~m}$ and $50 \mathrm{~cm} \times 50 \mathrm{~cm}$, respectively. Each mulch had three rows (each row contained two lines of plants) $1 \mathrm{~m}$ apart from each other, and $1.5 \mathrm{~m}$ spacing was kept in between black polythene 
TABLE 1: Average monthly weather data during both of experimental seasons for both locations.

\begin{tabular}{lcccccc}
\hline \multirow{2}{*}{ Month } & \multicolumn{2}{c}{ Maximum temperature $\left({ }^{\circ} \mathrm{C}\right)$} & \multicolumn{2}{c}{ Minimum temperature $\left({ }^{\circ} \mathrm{C}\right)$} & \multicolumn{2}{c}{ Rainfall $(\mathrm{mm})$} \\
& Joydebpur, Gazipur & Burirhat, Rangpur & Joydebpur, Gazipur & Burirhat, Rangpur & Joydebpur, Gazipur & Burirhat, Rangpur \\
\hline December & 26.92 & 23.55 & 13.87 & 13.31 & 4.04 & 0 \\
January & 25.17 & 22.19 & 11.42 & 10.71 & 0.13 & 19 \\
February & 29.15 & 25.83 & 15.05 & 13.52 & 17.8 & 5.77 \\
March & 33.15 & 30.86 & 19.95 & & 16.38 & 2.67 \\
\hline
\end{tabular}

TABLE 2: Initial soil nutrient status for both experimental sites.

\begin{tabular}{lccccc}
\hline \multirow{2}{*}{ Nutrient element } & \multicolumn{2}{c}{ Soil test value } & Critical level & \multicolumn{2}{c}{ Soil test interpretation } \\
& Joydebpur, Gazipur & Burirhat, Rangpur & & Joydebpur, Gazipur & Burirhat, Rangpur \\
\hline pH & 6.2 & 5.6 & - & Slightly acidic & Medium acidic \\
Organic matter (\%) & 0.95 & 1.23 & 2.0 & Low & Low \\
Ca (meq/100 g soil) & 1.12 & 0.82 & 0.5 & Low & Low \\
Mg (meq/100g soil) & 0.60 & 0.25 & 0.12 & Low & Low \\
Total $N$ (\%) & 0.08 & 0.06 & 0.12 & Low & Low \\
Available P (ppm) & 9 & 11.1 & 10 & Low & Low \\
K (meq/100g soil) & 0.17 & 0.11 & 0.6 & Medium & Low \\
S (ppm) & 10 & 2.05 & 0.2 & Low & Low \\
Zn (ppm) & 1.4 & 0.41 & 0.03 & & Low \\
B (ppm) & 0.10 & &
\end{tabular}

mulch and rice straw mulch to prevent the water from going to other plots and affecting them. The initial soil characteristics were analyzed (Table 2 ) for both locations. Fertilizer was applied based on the soil test results and Fertilizer Recommendation Guide, Bangladesh, 2012, at the rate of 120, 40, $110,25,4$, and $2 \mathrm{~kg} /$ ha of $\mathrm{N}, \mathrm{P}, \mathrm{K}, \mathrm{S}, \mathrm{Zn}$, and $\mathrm{B}$, respectively. The entire amount of cow dung ( $5 \mathrm{t} / \mathrm{ha})$, half MoP, and all of other fertilizers except urea were applied as basal and were incorporated into the soil during final land preparation. The urea was applied as top dress in three equal installments at 15, 30, and 45 DAT (days after transplanting), respectively. Rest half of MoP was applied at 45 DAT. Common irrigations (on an avg. $65 \mathrm{~mm}$ for Gazipur and $72 \mathrm{~mm}$ for Rangpur) were applied till plant establishment. Intercultural operations such as weeding and earthing up were done as and when necessary. For mulching, $13.5 \mathrm{~kg}$ straw mulch was used where the thickness of straw was $2 \mathrm{~cm}$. Black polythene mulch with 25 -micron thickness were used to cover the entire plot. Both mulches were installed manually on the entire bed. Black plastic mulch with small holes was stretched tightly on soil surface after 40 days from transplanting for strawberry seedlings to grow up. The crop was first harvested on the first week of February in both years.

2.4. Soil Moisture and Irrigation Water Requirement. Initial soil moisture was measured using the gravimetric method. Soil moisture prior to each irrigation and at the time of harvest was determined by the same method. Irrigation water was applied to bring the soil moisture up to field capacity, considering the effective root zone depth. Irrigation treatments began after the plant establishment. Irrigation was applied to each plot in basins by the hose pipe based on the calculated irrigation water.
Irrigation water was calculated using the following equation [22]:

$$
d=\frac{\mathrm{FC}-\mathrm{MC}_{i}}{100} \times A_{\mathrm{s}} \times D
$$

where $d$ is the depth of irrigation $(\mathrm{cm}), \mathrm{FC}$ is the field capacity of the soil (\%), $\mathrm{MC}_{i}$ is the moisture content of the soil before irrigation (\%), $A_{\mathrm{s}}$ is the apparent specific gravity of the soil, and $D$ is the depth of the effective root zone $(\mathrm{cm})$.

Seasonal water requirement was calculated using the water balance equation as follows:

Seasonal water requirement $(\mathrm{mm})=$ total irrigation water applied $(\mathrm{mm})+$ seasonal effective rainfall $(\mathrm{mm})+$ soil water contribution $(\mathrm{mm})$.

2.5. Data Collection and Data Analysis. Data on yield, yieldcontributing parameters, soil moisture, soil temperature, irrigation water requirement, and so on were recorded time to time. Growth and yield data were statistically analyzed using MSTAT-C program, and the treatment means were separated by DMRT at 5\% level of probability.

\section{Results and Discussion}

3.1. Available Soil Moisture. The moisture content was varied with the irrigation interval for different treatments. The plot with frequent interval irrigation was comparatively in more moisturized condition than others. Black polythene mulch retained higher moisture than rice straw mulch in most of the times (Figure 1). This finding agrees with Kumar and Dey [14]. This might be the fact that black polythene mulch acts as an insulating substance that condenses the 


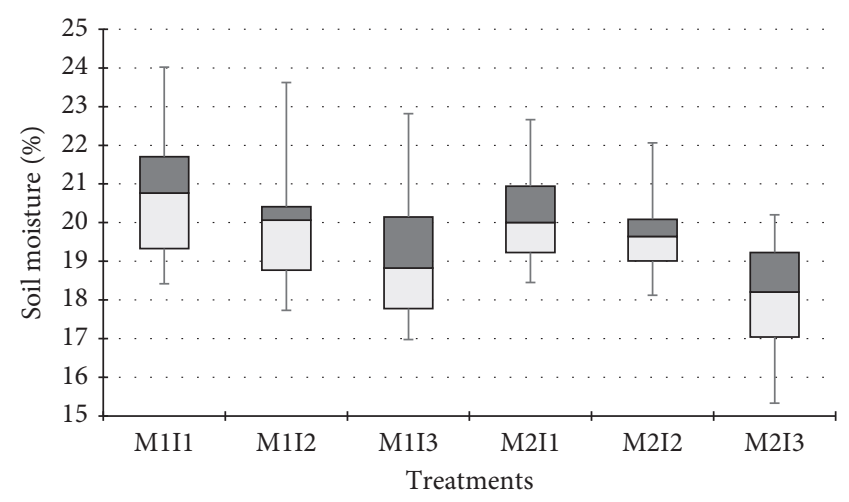

FIgURE 1: Effect of irrigation and mulches on the soil moisture content in different soil layers. $M_{1}=$ black polythene mulch; $M_{2}=$ rice straw mulch; $I_{1}=$ irrigation up to field capacity at 5 days interval after plant establishment (PE); $I_{2}=$ irrigation up to field capacity at 10 days interval after PE; $I_{3}=$ irrigation up to field capacity at 15 days interval after PE.

evaporating soil moisture inside the mulch and again drops it down to the soil surface [23]. Improvement of water infiltration and higher water retention capacity is also resulted from mulches reported by Swenson et al. [24] and Headu and Kumar [25]. In Figure 1, the black part indicates that most of the value of soil moisture was in this range during the entire cropping season. The possibility of soil moisture was high in the black polythene mulch plot compared to rice straw mulch plot. There was also a possibility of low moisture level in rice straw mulch with a longer irrigation interval.

3.2. Soil Temperature. Soil temperature was measured below the soil surface ( $1 \mathrm{~cm}$ below) once in a week. Black polythene mulch treatment always retains higher soil temperature compared to rice straw mulch (Table 3 ). Increase in soil temperature under black plastic mulch and minimum soil temperature under rice straw mulch had been reported by Tariq et al. [23]. This finding agrees with Diaz-Perez et al. [26]. Kumar and Dey found that, on the other hand, hay mulch is more effective than black polythene mulch for raising minimum soil temperature and lowering maximum soil temperature [27].

3.3. Combined Effect of Irrigation and Mulch. The yield and all yield-contributing characters were performed well for both locations. Different levels of irrigation water and mulch (black polythene and rice straw) had significant effect on all yield-contributing characters and yield for both locations.

\subsubsection{Growth Parameters}

(1) Plant Growth, Leaf, Flowering, and Harvesting. For Joydebpur, Gazipur, the taller plant, higher number of leaves per plant, and longer leaf length were observed when irrigating field at 5 days irrigation interval (Tables 4 and 5)
TABLE 3: Soil temperature $\left({ }^{\circ} \mathrm{C}\right)$ under both mulches collected once in a week (December-March).

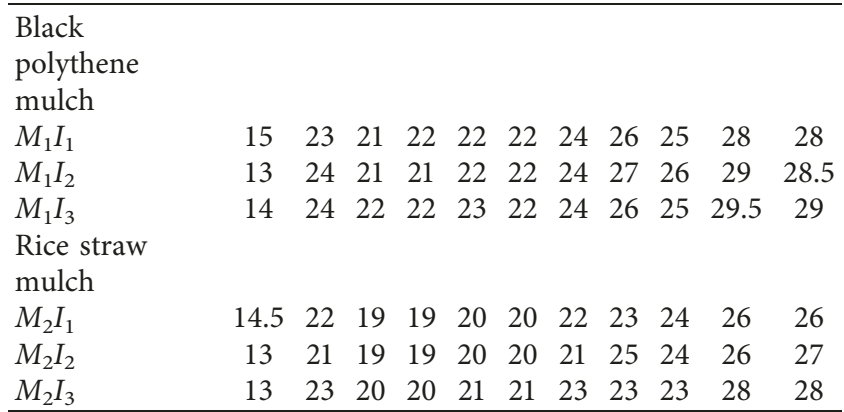

$M_{1}=$ black polythene mulch; $M_{2}$ = rice straw mulch; $I_{1}=$ irrigation up to field capacity at 5 days interval after plant establishment (PE); $I_{2}=$ irrigation up to field capacity at 10 days interval after plant establishment (PE); $I_{3}=$ irrigation up to field capacity at 15 days interval after plant establishment (PE).

compared to 10 and 15 days irrigation interval of same mulch. This could be because of the fact that the more moisturized condition due to frequent irrigation helps in enhancing the vegetative growth. The combined effect of irrigation and mulch showed that black polythene mulch with 5 days irrigation interval $\left(M_{2} I_{1}\right)$ performed better than rice straw mulch $\left(M_{1} I_{1}\right)$ with 5 days irrigation interval in case of plant height, number of leaves per plant, and leaf length for the two consecutive seasons. Tariq et al. [23] found that black polythene mulch performed better in the case of vegetative growth and yield followed by rice straw mulch for strawberry cultivation. Availability of soil moisture and optimum soil temperature under the mulched condition enhanced the plant height during the vegetative period. Days to 50\% flowering and days of first harvest were always earlier in black polythene mulch compare to rice straw mulch. Similar findings were observed from Soliman et al. [28]. Kumar et al. found that plants mulched with black polythene have significantly better growth, early flowering and fruiting, and produced larger fruit and higher yield of strawberry [29]. Similar observation was found by Pandey et al. [30].

For Burirhat, Rangpur, taller plant, higher number of leaves, and longer leaf length were found in black polythene mulch with 5 days irrigation interval (Table 6). Plants mulched with black polythene recorded maximum plant height and maximum number of leaves per plant over other mulching materials [20]. Kaur and Kaur found that vegetative growth parameters of strawberry increased when plants mulched with black polythene [31]. In both the years, early flowering, fruiting, and harvesting were found in black polythene mulch (Table 7) compared to rice straw mulch because black polythene raises soil temperature by absorbing heat in the planting bed that promotes faster development and earlier yields. Besides this, black polythene suppressed weeds as there was absent of light for photosynthesis under plastic film [32].

Since irrigation intervals in treatment $I_{3}$ (15 days irrigation interval) were comparatively longer, the plant faced water stress, and as a result of treatment $I_{3}$ gave the lowest results for both mulches. 
TABLE 4: Effect of irrigation and mulch on plant growth, flowering, and harvesting time of strawberry for Joydebpur, Gazipur.

\begin{tabular}{|c|c|c|c|c|c|c|}
\hline \multirow[b]{2}{*}{ Treatments } & \multicolumn{3}{|c|}{ Year 1} & \multicolumn{3}{|c|}{ Year 2} \\
\hline & $\begin{array}{l}\text { Plant height } \\
(\mathrm{cm})\end{array}$ & $\begin{array}{c}\text { Days to } 50 \% \\
\text { flowering }\end{array}$ & $\begin{array}{c}\text { Days of 1st } \\
\text { harvest }\end{array}$ & $\begin{array}{l}\text { Plant height } \\
(\mathrm{cm})\end{array}$ & $\begin{array}{c}\text { Days to } 50 \% \\
\text { flowering }\end{array}$ & $\begin{array}{c}\text { Days of 1st } \\
\text { harvest }\end{array}$ \\
\hline \multicolumn{7}{|c|}{$\begin{array}{l}\text { Black polythene } \\
\text { mulch }\end{array}$} \\
\hline$M_{1} I_{1}$ & $16.53^{\mathrm{a}}$ & $63^{c}$ & $84.33^{\mathrm{d}}$ & $16.22^{\mathrm{a}}$ & $52.33^{c}$ & $71^{\mathrm{d}}$ \\
\hline$M_{1} I_{2}$ & $14.20^{\mathrm{bc}}$ & $68^{\mathrm{ab}}$ & $90^{c}$ & $15.00^{\mathrm{bc}}$ & $56.33^{\mathrm{b}}$ & $75^{\mathrm{c}}$ \\
\hline$M_{1} I_{3}$ & $12.87^{\mathrm{c}}$ & $70^{\mathrm{ab}}$ & $95^{\mathrm{ab}}$ & $14.44^{\mathrm{d}}$ & $58.67^{\mathrm{a}}$ & $79^{\mathrm{b}}$ \\
\hline \multicolumn{7}{|c|}{ Rice straw mulch } \\
\hline$M_{2} I_{1}$ & $16.27^{\mathrm{ab}}$ & $66^{\mathrm{bc}}$ & $85.50^{\mathrm{d}}$ & $16.67^{\mathrm{a}}$ & $56.67^{\mathrm{b}}$ & $74.67^{\mathrm{c}}$ \\
\hline$M_{2} I_{2}$ & $14.33^{\mathrm{abc}}$ & $70^{\mathrm{ab}}$ & $92.5^{\mathrm{bc}}$ & $15.45^{\mathrm{b}}$ & $59^{\mathrm{a}}$ & $81 \mathrm{~b}$ \\
\hline$M_{2} I_{3}$ & $12.53^{\mathrm{c}}$ & $72^{\mathrm{a}}$ & $96.50^{\mathrm{a}}$ & $14.67^{\mathrm{cd}}$ & $60^{\mathrm{a}}$ & $86.33^{\mathrm{a}}$ \\
\hline CV (\%) & 7.97 & 3.36 & 2.15 & 1.61 & 1.84 & 1.85 \\
\hline
\end{tabular}

Means having same or without letter(s) do not differ significantly at 5\% level of probability. $M_{1}=$ black polythene mulch; $M_{2}=$ rice straw mulch; $I_{1}=$ irrigation up to field capacity at 5 days interval after plant establishment (PE); $I_{2}=$ irrigation up to field capacity at 10 days interval after PE; $I_{3}=$ irrigation up to field capacity at 15 days interval after PE.

TABLE 5: Effect of irrigation and mulch on vegetative and yield parameters of strawberry in Joydebpur, Gazipur, for two consecutive seasons.

\begin{tabular}{|c|c|c|c|c|c|c|c|c|}
\hline \multirow[b]{2}{*}{ Treatments } & \multicolumn{4}{|c|}{ Year 1} & \multicolumn{4}{|c|}{ Year 2} \\
\hline & $\begin{array}{l}\text { Leaves per plant } \\
\text { (number) }\end{array}$ & $\begin{array}{l}\text { Leaves } \\
\text { length }(\mathrm{cm})\end{array}$ & $\begin{array}{l}\text { Fruit length } \\
\qquad(\mathrm{cm})\end{array}$ & $\begin{array}{c}\text { Fruit } \\
\text { diameter } \\
(\mathrm{cm})\end{array}$ & $\begin{array}{l}\text { Leaves per plant } \\
\text { (number) }\end{array}$ & $\begin{array}{l}\text { Leaves } \\
\text { length }(\mathrm{cm})\end{array}$ & $\begin{array}{l}\text { Fruit length } \\
\qquad(\mathrm{cm})\end{array}$ & $\begin{array}{c}\text { Fruit } \\
\text { diameter } \\
(\mathrm{cm})\end{array}$ \\
\hline$M_{1} I_{1}$ & $21^{\mathrm{a}}$ & $16.33^{\mathrm{a}}$ & $4.64^{\mathrm{a}}$ & 3.12 & $16.22^{\mathrm{a}}$ & $15.78^{\mathrm{a}}$ & $4.48^{\mathrm{ab}}$ & $3.22^{\mathrm{abc}}$ \\
\hline$M_{1} I_{2}$ & $15.07^{\mathrm{cd}}$ & $13.67^{\mathrm{cd}}$ & $3.93^{\mathrm{b}}$ & 2.93 & $14.33^{\mathrm{ab}}$ & $12.78^{\mathrm{bc}}$ & $4.02^{\mathrm{b}}$ & $3.08^{\mathrm{bc}}$ \\
\hline$M_{1} I_{3}$ & $13.13^{\mathrm{d}}$ & $12.33^{\mathrm{d}}$ & $3.89^{\mathrm{b}}$ & 2.88 & $13.56^{\mathrm{b}}$ & $12.14^{\mathrm{c}}$ & $4.17^{\mathrm{b}}$ & $3.01^{\mathrm{c}}$ \\
\hline$M_{2} I_{1}$ & $17.73^{\mathrm{b}}$ & $15.27^{\mathrm{ab}}$ & $4.44^{\mathrm{a}}$ & 3.13 & $15.33^{\mathrm{ab}}$ & $14.00^{\mathrm{b}}$ & $4.78^{\mathrm{a}}$ & $3.37^{\mathrm{a}}$ \\
\hline$M_{2} I_{2}$ & $16.13^{\mathrm{bc}}$ & $13.93^{\mathrm{bc}}$ & $4.42^{\mathrm{a}}$ & 3.15 & $15.56^{\mathrm{ab}}$ & $13.00^{\mathrm{bc}}$ & $4.43^{\mathrm{ab}}$ & $3.29^{\mathrm{ab}}$ \\
\hline$M_{2} I_{3}$ & $15.87^{\mathrm{bc}}$ & $12.33^{\mathrm{d}}$ & $4.36^{\mathrm{a}}$ & 3.07 & $13.89^{\mathrm{ab}}$ & $12.67^{\mathrm{bc}}$ & $4.23^{\mathrm{b}}$ & $3.01^{\mathrm{c}}$ \\
\hline CV (\%) & 7.95 & 5.25 & 5.01 & 4.79 & 7.78 & 5.01 & 5.84 & 3.75 \\
\hline
\end{tabular}

Means having same or without letter(s) do not differ significantly at 5\% level of probability. $M_{1}=$ black polythene mulch; $M_{2}=$ rice straw mulch; $I_{1}=$ irrigation up to field capacity at 5 days interval after plant establishment (PE); $I_{2}=$ irrigation up to field capacity at 10 days interval after plant establishment (PE); $I_{3}=$ irrigation up to field capacity at 15 days interval after plant establishment $(\mathrm{PE})$.

TABLE 6: Effect of irrigation and mulch on vegetative and yield parameters of strawberry in Burirhat, Rangpur, for two consecutive seasons.

\begin{tabular}{|c|c|c|c|c|c|c|c|c|}
\hline \multirow[b]{2}{*}{ Treatments } & \multicolumn{4}{|c|}{ Year 1} & \multicolumn{4}{|c|}{ Year 2} \\
\hline & $\begin{array}{l}\text { Leaves per plant } \\
\text { (number) }\end{array}$ & $\begin{array}{c}\text { Leaves } \\
\text { length }(\mathrm{cm})\end{array}$ & $\begin{array}{l}\text { Fruit length } \\
\quad(\mathrm{cm})\end{array}$ & $\begin{array}{c}\text { Fruit } \\
\text { diameter } \\
(\mathrm{cm})\end{array}$ & $\begin{array}{l}\text { Leaves per plant } \\
\text { (number) }\end{array}$ & $\begin{array}{l}\text { Leaves } \\
\text { length }(\mathrm{cm})\end{array}$ & $\begin{array}{l}\text { Fruit length } \\
\quad(\mathrm{cm})\end{array}$ & $\begin{array}{c}\text { Fruit } \\
\text { diameter } \\
(\mathrm{cm})\end{array}$ \\
\hline$M_{1} I_{1}$ & $18.73^{\mathrm{ab}}$ & $16.20^{\mathrm{a}}$ & $3.80^{\mathrm{b}}$ & $2.54^{\mathrm{a}}$ & $35.01^{\mathrm{ab}}$ & 14.00 & $4.12^{\mathrm{a}}$ & $3.50^{\mathrm{a}}$ \\
\hline$M_{1} I_{2}$ & $19.90^{\mathrm{a}}$ & $15.50^{\mathrm{ab}}$ & $3.60^{c}$ & $2.49^{\mathrm{a}}$ & $36.34^{\mathrm{a}}$ & 13.27 & $3.87^{\mathrm{b}}$ & $3.19^{b c}$ \\
\hline$M_{1} I_{3}$ & $17.00^{\mathrm{bc}}$ & $13.78^{\mathrm{c}}$ & $3.50^{\mathrm{d}}$ & $2.46^{\mathrm{ab}}$ & $28.12^{\mathrm{bc}}$ & 12.47 & $3.56^{\mathrm{c}}$ & $2.82^{\mathrm{d}}$ \\
\hline$M_{2} I_{1}$ & $16.40^{\mathrm{c}}$ & $15.10^{\mathrm{ab}}$ & $3.80^{\mathrm{b}}$ & $2.51^{\mathrm{a}}$ & $27.56^{\mathrm{bc}}$ & 13.20 & $3.90^{\mathrm{b}}$ & $3.37^{\mathrm{ab}}$ \\
\hline$M_{2} I_{2}$ & $19.00^{\mathrm{ab}}$ & $14.93^{\mathrm{bc}}$ & $3.90^{\mathrm{a}}$ & $2.60^{\mathrm{a}}$ & $24.00^{\mathrm{c}}$ & 13.00 & $3.63^{\mathrm{c}}$ & $3.09^{\mathrm{cd}}$ \\
\hline$M_{2} I_{3}$ & $17.07^{\mathrm{bc}}$ & $14.26^{\mathrm{bc}}$ & $3.63^{\mathrm{c}}$ & $2.34^{\mathrm{b}}$ & $20.56^{\mathrm{c}}$ & 11.77 & $3.48^{\mathrm{c}}$ & $2.90^{\mathrm{d}}$ \\
\hline CV (\%) & 7.08 & 4.56 & 1.47 & 3.10 & 14.85 & 2.45 & 2.50 & 4.75 \\
\hline
\end{tabular}

Means having same or without letter(s) do not differ significantly at $5 \%$ level of probability. $M_{1}=$ black polythene mulch; $M_{2}=$ rice straw mulch; $I_{1}=$ irrigation up to field capacity at 5 days interval after plant establishment (PE); $I_{2}=$ irrigation up to field capacity at 10 days interval after plant establishment (PE); $I_{3}=$ irrigation up to field capacity at 15 days interval after plant establishment (PE).

3.3.2. Yield Parameters. In Joydebpur, Gazipur, the combined effect of irrigation and mulch results showed significant differences among different treatments. From all the treatments, it is found that irrigation at 5 days interval with rice straw mulch $\left(M_{2} I_{1}\right)$ gave the higher yield closely followed by irrigation at 5 days interval with black polythene mulch $\left(M_{1} I_{1}\right)$ (Table 8). Among different treatments, the plant grown under plastic mulch produced larger number of fruits, fruit weight, and finally contributed to yield. Saeid and Mohammed [33] also found the same results because of better plant growth due to favorable hydrothermal regime and complete weed free environment. Strawberry plants, when mulched with black polythene film, produced more number of fruits which ultimately resulted in highest strawberry production compared to other types of mulches found by Castaneda et al. [34]. Kher et al. found that higher 
TABLE 7: Effect of irrigation and mulch on plant growth, flowering, and harvesting time of strawberry in Burirhat, Rangpur.

\begin{tabular}{|c|c|c|c|c|c|c|}
\hline \multirow[b]{2}{*}{ Treatments } & \multicolumn{3}{|c|}{ Year 1} & \multicolumn{3}{|c|}{ Year 2} \\
\hline & $\begin{array}{l}\text { Plant height } \\
(\mathrm{cm})\end{array}$ & $\begin{array}{c}\text { Days to } 50 \% \\
\text { flowering }\end{array}$ & $\begin{array}{c}\text { Days of 1st } \\
\text { harvest }\end{array}$ & $\begin{array}{l}\text { Plant height } \\
(\mathrm{cm})\end{array}$ & $\begin{array}{c}\text { Days to } 50 \% \\
\text { flowering }\end{array}$ & $\begin{array}{c}\text { Days of } 1 \text { st } \\
\text { harvest }\end{array}$ \\
\hline \multicolumn{7}{|c|}{$\begin{array}{l}\text { Black polythene } \\
\text { mulch }\end{array}$} \\
\hline$M_{1} I_{1}$ & $17.60^{\mathrm{a}}$ & $67.11^{\mathrm{b}}$ & $89^{\mathrm{d}}$ & 18.78 & $59^{\mathrm{d}}$ & $81.67^{\mathrm{c}}$ \\
\hline$M_{1} I_{2}$ & $16.67^{\mathrm{ab}}$ & $70.89^{\mathrm{ab}}$ & $94^{\mathrm{c}}$ & 17.50 & $63^{\text {bd }}$ & $84^{\mathrm{b}}$ \\
\hline$M_{1} I_{3}$ & $15.13^{\mathrm{b}}$ & $72^{\mathrm{ab}}$ & $97^{\mathrm{b}}$ & 14.62 & $66^{\mathrm{ab}}$ & $87.33^{\mathrm{a}}$ \\
\hline \multicolumn{7}{|c|}{ Rice straw mulch } \\
\hline$M_{2} I_{1}$ & $15.90^{\mathrm{b}}$ & $74.63^{\mathrm{a}}$ & $92^{\mathrm{c}}$ & 16.61 & $61^{\mathrm{cd}}$ & $83^{\mathrm{bc}}$ \\
\hline$M_{2} I_{2}$ & $16.60^{\mathrm{ab}}$ & $73^{\mathrm{ab}}$ & $97^{\mathrm{b}}$ & 15.45 & $65^{\mathrm{bc}}$ & $86.67^{\mathrm{a}}$ \\
\hline$M_{2} I_{3}$ & $15.27^{\mathrm{b}}$ & $73.89^{\mathrm{a}}$ & $101^{\mathrm{a}}$ & 14 & $69.67^{\mathrm{a}}$ & $88.67^{\mathrm{a}}$ \\
\hline CV (\%) & 5.36 & 10.6 & 1.36 & 6.46 & 3.75 & 1.35 \\
\hline
\end{tabular}

Means having same or without letter(s) do not differ significantly at $5 \%$ level of probability. $M_{1}=$ black polythene mulch; $M_{2}=$ rice straw mulch; $I_{1}=$ irrigation up to field capacity at 5 days interval after plant establishment (PE); $I_{2}=$ irrigation up to field capacity at 10 days interval after PE; $I_{3}=$ irrigation up to field capacity at 15 days interval after PE.

TABLE 8: Effect of irrigation and mulch on the yield and yield-contributing characters of strawberry for Joydebpur, Gazipur.

\begin{tabular}{|c|c|c|c|c|c|c|}
\hline \multirow[b]{2}{*}{ Treatments } & \multicolumn{3}{|c|}{ Year 1} & \multicolumn{3}{|c|}{ Year 2} \\
\hline & $\begin{array}{c}\text { Fruits per plant } \\
\text { (number) }\end{array}$ & $\begin{array}{l}\text { Individual fruit } \\
\text { weight }(\mathrm{g})\end{array}$ & $\begin{array}{l}\text { Yield } \\
(\mathrm{t} / \mathrm{ha})\end{array}$ & $\begin{array}{c}\text { Fruits per plant } \\
\text { (number) }\end{array}$ & $\begin{array}{l}\text { Individual fruit } \\
\text { weight }(\mathrm{g})\end{array}$ & $\begin{array}{l}\text { Yield } \\
\text { (t/ha) }\end{array}$ \\
\hline \multicolumn{7}{|c|}{$\begin{array}{l}\text { Black polythene } \\
\text { mulch }\end{array}$} \\
\hline$M_{1} I_{1}$ & $22.67^{\mathrm{a}}$ & $21.77^{\mathrm{a}}$ & $11.68^{\mathrm{a}}$ & $18.27^{\mathrm{a}}$ & $22^{\mathrm{a}}$ & $12.07^{\mathrm{a}}$ \\
\hline$M_{1} I_{2}$ & $12.90^{\mathrm{cd}}$ & $17.39^{\mathrm{bc}}$ & $5.94^{\mathrm{bc}}$ & $15.60^{\mathrm{b}}$ & $19.20^{\mathrm{bc}}$ & $10.32^{\mathrm{c}}$ \\
\hline$M_{1} I_{3}$ & $11.63^{\mathrm{d}}$ & $16.64^{\mathrm{c}}$ & $4.84^{\mathrm{c}}$ & $11.03^{\mathrm{c}}$ & $18.26^{\mathrm{c}}$ & $6.87^{\mathrm{e}}$ \\
\hline \multicolumn{7}{|c|}{ Rice straw mulch } \\
\hline$M_{2} I_{1}$ & $19.43^{\mathrm{b}}$ & $21.88^{\mathrm{a}}$ & $11.98^{\mathrm{a}}$ & $19.10^{\mathrm{a}}$ & $25.00^{\mathrm{a}}$ & $12.30^{\mathrm{a}}$ \\
\hline$M_{2} I_{2}$ & $18.60^{\mathrm{b}}$ & $20.43^{\mathrm{ab}}$ & $10.46^{\mathrm{a}}$ & $15.30^{\mathrm{b}}$ & $21.11^{b c}$ & $11.33^{\mathrm{b}}$ \\
\hline$M_{2} I_{3}$ & $13.53^{\mathrm{c}}$ & $20.19^{\mathrm{ab}}$ & $7.43^{\mathrm{b}}$ & $13.70^{\mathrm{c}}$ & $19.19^{b c}$ & $7.93^{\mathrm{d}}$ \\
\hline CV (\%) & 4.38 & 8.99 & 5.62 & 6.55 & 8.71 & 2.31 \\
\hline
\end{tabular}

Means having same or without letter(s) do not differ significantly at 5\% level of probability. $M_{1}=$ black polythene mulch; $M_{2}=$ rice straw mulch; $I_{1}=$ irrigation up to field capacity at 5 days interval after plant establishment (PE); $I_{2}=$ irrigation up to field capacity at 10 days interval after PE; $I_{3}=$ irrigation up to field capacity at 15 days interval after PE.

vegetative growth and the higher number of fruits per plant were observed under black polythene mulch [35]. Kumar and Dey [14] and Bakshi et al. [20] also reported the same results. In case of yield, though there were no statistically significant differences for 5 days irrigation interval between both mulches, there were significant differences for 10 and 15 days irrigation interval for both mulches. Fruit weight decreased from the maximum of $21.77 \mathrm{~g}$ with 5 days irrigation intervals to the minimum of $16.64 \mathrm{~g}$ with 15 days irrigation interval in the first year. The decrease in the fruit weight from 5 to 15 days irrigation interval was $23.6 \%$ in the first year and $17 \%$ in the second year for black polythene mulch. For rice straw mulch, it was about 7\% in the first year and $23 \%$ in the second year. However, the difference in 5 to 15 days irrigation interval had a significant effect on fruit weight for both the years. Yuan et al. [36] found that increasing irrigation frequency causes cell expansion of fruit and that ultimately increases fruit weight. Akhtar and Rab [37] reported that the maximum fresh fruit weight, moisture content, and ascorbic acid content were found when strawberry plants irrigated at 4 days interval compared to longer irrigation interval. On the other hand, Liu et al. [38] found that fresh weight and water content of strawberry had decreased due to longer irrigation intervals or partial root drying.

However, finally it is found that rice straw mulch at 5 days irrigation interval performs better in Joydebpur, Gazipur (Table 8 and Figure 2). Because initially black polythene mulch performed well for the vegetative growth, yield, and all yieldcontributing characters, but the favorable condition by using black polythene mulch did not sustain for the rest of the growing period. The possible reason could be that temperature was rising during the crop growing period day by day. This rising temperature possibly created warmer condition beneath the black polythene mulch and resulted in an unfavorable environment for the strawberry plants to survive. Fruits were getting smaller in size, leaves were burned, and finally plants died. Singh and Yadav [16] observed that fruits from the plant covered by black polythene can be damaged in very hot and sunny weather in the strawberry production under field condition. All yield-contributing characters and yield results revealed that 15 days irrigation interval with black polythene mulch $\left(M_{1} I_{3}\right)$ will not suit for strawberry production in Joydebpur, Gazipur. 


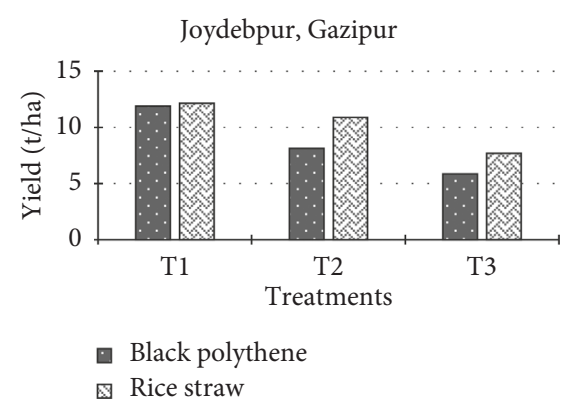

(a)

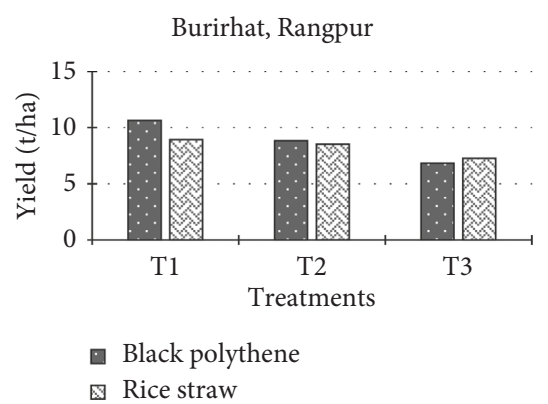

(b)

Figure 2: Effect of irrigation and mulches on the yield (average of both years) of strawberry for both locations.

TABLE 9: Effect of irrigation mulch on the yield and yield-contributing characters of strawberry in Burirhat, Rangpur.

\begin{tabular}{|c|c|c|c|c|c|c|}
\hline \multirow[b]{2}{*}{ Treatments } & \multicolumn{3}{|c|}{ Year 1} & \multicolumn{3}{|c|}{ Year 2} \\
\hline & $\begin{array}{l}\text { Fruits per plant } \\
\text { (number) }\end{array}$ & $\begin{array}{l}\text { Individual fruit } \\
\text { weight (g) }\end{array}$ & $\begin{array}{l}\text { Yield } \\
\text { (t/ha) }\end{array}$ & $\begin{array}{l}\text { Fruits per plant } \\
\text { (number) }\end{array}$ & $\begin{array}{l}\text { Individual fruit } \\
\text { weight }(\mathrm{g})\end{array}$ & $\begin{array}{l}\text { Yield } \\
\text { (t/ha) }\end{array}$ \\
\hline \multicolumn{7}{|c|}{$\begin{array}{l}\text { Black polythene } \\
\text { mulch }\end{array}$} \\
\hline$M_{1} I_{1}$ & $14.67^{\mathrm{a}}$ & $16.33^{\mathrm{a}}$ & $9.56^{\mathrm{a}}$ & $24.56^{\mathrm{a}}$ & 17.17 & $11.74^{\mathrm{a}}$ \\
\hline$M_{1} I_{2}$ & $13.83^{\mathrm{ab}}$ & $15.07^{\mathrm{b}}$ & $7.90^{\mathrm{b}}$ & $19.45^{b c}$ & 16.40 & $9.76^{\mathrm{bc}}$ \\
\hline$M_{1} I_{3}$ & $11.83^{\mathrm{cd}}$ & $14.13^{\mathrm{c}}$ & $6.66^{\mathrm{c}}$ & $13.00^{\mathrm{d}}$ & 13.50 & $7.01^{\mathrm{d}}$ \\
\hline \multicolumn{7}{|c|}{ Rice straw mulch } \\
\hline$M_{2} I_{1}$ & $12.17^{\mathrm{cd}}$ & $15.10^{\mathrm{b}}$ & $7.35^{\mathrm{bc}}$ & $20.17^{\mathrm{b}}$ & 16.30 & $10.53^{\mathrm{ab}}$ \\
\hline$M_{2} I_{2}$ & $12.67^{\mathrm{bc}}$ & $15.47^{\mathrm{b}}$ & $7.73^{b c}$ & $17.50^{\mathrm{c}}$ & 15.70 & $9.27^{\mathrm{bc}}$ \\
\hline$M_{2} I_{3}$ & $10.67^{\mathrm{d}}$ & $13.93^{\mathrm{c}}$ & $5.94^{\mathrm{d}}$ & $15.00^{\mathrm{d}}$ & 14.30 & $8.60^{c}$ \\
\hline CV (\%) & 6.57 & 2.23 & 8.53 & 6.25 & 4.14 & 8.45 \\
\hline
\end{tabular}

Means having same or without letter(s) do not differ significantly at 5\% level of probability. $M_{1}=$ black polythene mulch; $M_{2}=$ rice straw mulch; $I_{1}=$ irrigation up to field capacity at 5 days interval after plant establishment (PE); $I_{2}=$ irrigation up to field capacity at 10 days interval after PE; $I_{3}=$ irrigation up to field capacity at 15 days interval after PE.

But in the case of Burirhat, Rangpur, irrigation at 5 days interval with black polythene mulch $\left(M_{1} I_{1}\right)$ showed better results considering all yield-contributing characters and yield compared to mulching with rice straw at 5 days irrigation interval for both the years (Table 9 and Figure 2). Kaur and Kaur [31] reported that application of black polythene mulch enhanced yield and yield parameters than other mulches. Sharma and Goel [39] found that the maximum yield was obtained from black polythene mulch compared to wheat and rice straw mulches for the strawberry production. The present findings of this study are in accordance with the previous researchers $[23,28,30,40]$ who reported significantly higher yield under black plastic mulch because of effective soil temperature, weed control, and conservation of soil moisture for the strawberry cultivation. The above results and discussion under Section 3.3 revealed that 5 days interval irrigation in the strawberry field during the growing season brought better vegetative growth, flowering, fruiting, and yield for both locations. Black polythene/rice straw played as a supportive material for the higher yield of strawberry in both locations. In the regions which contain comparatively low temperatures, black polythene mulch may perform well for the entire growing season.

3.4. Water Use and Water Productivity. Seasonal water use and water productivity of strawberry under different irrigation treatments are presented in Tables 10 and 11 for both locations. The amount of irrigation water applied was increased with the increased irrigation frequency.

From all the treatments (Table 10), total water use was found maximum $(498.05 \mathrm{~mm}$ in the first year and $490.08 \mathrm{~mm}$ in the second year) in treatment $M_{2} I_{1}$, that is, when irrigating field at 5 days interval with rice straw mulch which was followed by irrigating field at 5 days interval with black polythene mulch (474.42 and $467.32 \mathrm{~mm}$ for two consecutive years) with the same irrigation frequency. Black polythene absorbs heat and conserves more moisture (Figure 1) than rice straw and for this reason comparatively less water was applied in black polythene mulched plot than rice straw mulched plot. Lowest water use was found in treatment $I_{3}$ due to lower frequency of irrigation for both mulches. Although total water use was the highest in treatment $M_{2} I_{1}$, the water productivity in terms of yield per unit water use was found to be the highest from $M_{2} I_{2}$ $\left(3.04 \mathrm{~kg} / \mathrm{m}^{3}\right.$ in the first year, $3.44 \mathrm{~kg} / \mathrm{m}^{3}$ in the second year, and $3.24 \mathrm{~kg} / \mathrm{m}^{3}$ avg. of both years) treatment. However, the lowest water productivity (avg. of both years) was obtained from $M_{1} I_{3}$ treatment in Joydebpur, Gazipur, due to lower irrigation frequency and lower yield.

In Burirhat, Rangpur, the highest irrigation water was used in the rice straw mulched plot followed by the black polythene mulched plot with the same irrigation frequency for both the years (Table 11). The highest water productivity was obtained from treatment $M_{1} I_{2}\left(3.49 \mathrm{~kg} / \mathrm{m}^{3}\right)$ in the 
TABLE 10: Irrigation frequency, seasonal water use, and water productivity for Joydebpur, Gazipur.

\begin{tabular}{lccccccc}
\hline Treatments & $\begin{array}{c}\text { Number of } \\
\text { irrigation } \\
\text { (number) }\end{array}$ & $\begin{array}{c}\text { Year } 1 \\
\text { Seasonal total } \\
\text { water use } \\
(\mathrm{mm})\end{array}$ & $\begin{array}{c}\text { Water } \\
\text { productivity } \\
\left(\mathrm{kg} / \mathrm{m}^{3}\right)\end{array}$ & $\begin{array}{c}\text { Number of } \\
\text { irrigation } \\
(\text { number })\end{array}$ & $\begin{array}{c}\text { Year } 2 \\
\text { Seasonal total } \\
\text { water use } \\
(\mathrm{mm})\end{array}$ & $\begin{array}{c}\text { Water } \\
\text { productivity } \\
\left(\mathrm{kg} / \mathrm{m}^{3}\right)\end{array}$ & $\begin{array}{c}\text { Average water } \\
\text { productivity for both } \\
\text { years }\left(\mathrm{kg} / \mathrm{m}^{3}\right)\end{array}$ \\
\hline$M_{1} I_{1}$ & 25 & 474.42 & 2.46 & 21 & 467.32 & 2.58 & 2.52 \\
$M_{1} I_{2}$ & 12 & 321.36 & 1.85 & 11 & 316.15 & 3.26 & 2.56 \\
$M_{1} I_{3}$ & 9 & 241.05 & 2.01 & 7 & 271.28 & 2.53 & 2.51 \\
$M_{2} I_{1}$ & 25 & 498.05 & 2.41 & 21 & 490.08 & 2.51 & 3.44 \\
$M_{2} I_{2}$ & 12 & 343.77 & 3.04 & 11 & 329.78 & 2.45 \\
$M_{2} I_{3}$ & 9 & 268.36 & 2.77 & 7 & 278.33 & 2.85 & 2.81 \\
\hline
\end{tabular}

$M_{1}=$ black polythene mulch; $M_{2}=$ rice straw mulch; $I_{1}=$ irrigation up to field capacity at 5 days interval after plant establishment (PE); $I_{2}=$ irrigation up to field capacity at 10 days interval after PE; $I_{3}=$ irrigation up to field capacity at 15 days interval after PE.

TABLE 11: Irrigation frequency, seasonal water use, and water productivity for Burirhat, Rangpur.

\begin{tabular}{|c|c|c|c|c|c|c|c|}
\hline \multirow[b]{2}{*}{ Treatments } & \multicolumn{3}{|c|}{ Year 1} & \multicolumn{3}{|c|}{ Year 2} & \multirow[b]{2}{*}{$\begin{array}{c}\text { Average water } \\
\text { productivity for both } \\
\text { years }\left(\mathrm{kg} / \mathrm{m}^{3}\right)\end{array}$} \\
\hline & $\begin{array}{l}\text { Number of } \\
\text { irrigation } \\
\text { (number) }\end{array}$ & $\begin{array}{l}\text { Seasonal total } \\
\text { water use } \\
(\mathrm{mm})\end{array}$ & $\begin{array}{c}\text { Water } \\
\text { productivity } \\
\left(\mathrm{kg} / \mathrm{m}^{3}\right)\end{array}$ & $\begin{array}{l}\text { Number of } \\
\text { irrigation } \\
\text { (number) }\end{array}$ & $\begin{array}{l}\text { Seasonal total } \\
\text { water use } \\
(\mathrm{mm})\end{array}$ & $\begin{array}{c}\text { Water } \\
\text { productivity } \\
\left(\mathrm{kg} / \mathrm{m}^{3}\right)\end{array}$ & \\
\hline$M_{1} I_{1}$ & 25 & 514.80 & 1.86 & 21 & 450.12 & 2.61 & 2.24 \\
\hline$M_{1} I_{2}$ & 12 & 365.90 & 2.16 & 11 & 279.27 & 3.49 & 2.83 \\
\hline$M_{1} I_{3}$ & 9 & 305.08 & 2.18 & 7 & 250.99 & 2.79 & 2.49 \\
\hline$M_{2} I_{1}$ & 25 & 553.10 & 1.33 & 21 & 489.80 & 2.15 & 1.74 \\
\hline$M_{2} I_{2}$ & 12 & 394.20 & 1.96 & 11 & 315.75 & 2.94 & 2.45 \\
\hline$M_{2} I_{3}$ & 9 & 317.30 & 1.87 & 7 & 262.54 & 3.28 & 2.58 \\
\hline
\end{tabular}

$M_{1}=$ black polythene mulch; $M_{2}=$ rice straw mulch; $I_{1}=$ irrigation up to field capacity at 5 days interval after plant establishment (PE); $I_{2}=$ irrigation up to field capacity at 10 days interval after PE; $I_{3}=$ irrigation up to field capacity at 15 days interval after PE.

second year and $2.83 \mathrm{~kg} / \mathrm{m}^{3}$ avg. for both the years, whereas the lowest water productivity $\left(1.74 \mathrm{~kg} / \mathrm{m}^{3}\right)$ was obtained from treatment $M_{2} I_{1}$ because of highest water use.

So, it can be stated that 10 days irrigation interval $\left(I_{2}\right)$ gave the highest water productivity for both locations, but the only difference is in mulching material between these locations.

\section{Conclusion}

Results revealed that 5 days irrigation interval was performed better with both types of mulches and both locations. In respect of yield, rice straw mulch along with 5 days irrigation interval in Gazipur and black polythene mulch along with 5 days irrigation interval in Rangpur were performed well. But considering water productivity, 10 days irrigation interval with rice straw mulch in Gazipur and 10 days interval with black polythene mulch for Rangpur showed highest results among all other treatments. It can be inferred that if water is available enough, then 5 days irrigation interval with rice straw mulch in Gazipur and 5 days interval with black polythene mulch in Rangpur could be an effective irrigation schedule for strawberry cultivation. But if water is limited and farmers are not capable enough to pay much attention on production, then considering water productivity 10 days irrigation interval with rice straw mulch in Gazipur and 10 days interval with black polythene mulch in Rangpur could be good practice for farmers to cultivate strawberry in Bangladesh and similar strawberry industry conditions.

\section{Disclosure}

Rahena Parvin Rannu is currently at Irrigation and Water Management Division, Bangladesh Agricultural Research Institute, Bangladesh. Abu Saleh Md. Yousuf Ali is currently at Regional Horticulture Research Station, Bangladesh Agricultural Research Institute, Bangladesh. Pijush Kanti Sarkar is currently at Department of Agricultural Engineering and Technology, Sylhet Agricultural University, Bangladesh.

\section{Conflicts of Interest}

The authors declare that they have no conflicts of interest to publish this article.

\section{Acknowledgments}

The authors are grateful to Bangladesh Agricultural Research Institute (BARI), Gazipur, for the financial support and Horticulture Research Centre (HRC), Irrigation and Water Management (IWM) Division, Gazipur, and Regional Agricultural Research Station (RARS), Rangpur, BARI for their facilities to execute this experiment. The authors also thank their colleagues and staff who supported during the study. 


\section{References}

[1] D. Monda, Possibility of Strawberry Cultivation in Bangladesh. An Assignment on Strawberry, Department of Business Administration, Northern University, Dhaka, Bangladesh, October 2017, https://www.scribd.com/doc/.../Possibility-of-StrawberryCultivation-in-Bangladesh.

[2] BSS, Newly Harvested Strawberry Arrives in Northern Markets, Bangladesh Sangbad Sangstha, Dhaka, Bangladesh, January 2017, http://www.bssnews.net/newsDetails.php?cat=0\&id=94716 $\$$ date $=2010-03-14 \&$ dateCurrent=2010-03-18.

[3] R. H. Firoz, Commercial Strawberry Cultivation on the Rise in Rajshahi, March 2018, http://www.observerbd.com/2016/02/ 10/135849.php.

[4] A. H. El-Farhan and M. P. Pritts, "Water requirements and water stress in strawberry," Advances in Strawberry Research, vol. 15, pp. 5-12, 1997.

[5] H. Kirnak, C. Kaya, D. Higgs, and S. Gercek, "A long-term experiment to study the role of mulches in the physiology and macro-nutrition of strawberry grown under water stress," Australian Journal of Agricultural Research, vol. 52, no. 9, pp. 937-943, 2001.

[6] E. Krüger, G. Schmidt, and S. Rasim, "Effect of irrigation on yield, fruit size and firmness of strawberry cv. Elsanta," in Proceedings of the IV International Strawberry Symposium, vol. 567, pp. 471-474, Tampere, Finland, 2000.

[7] L. Taparauskienè and O. Miseckaitè, "Effect of mulch on soil moisture depletion and strawberry yield in sub-humid area," Polish Journal of Environmental Studies, vol. 23, no. 2, pp. $475-482,2014$.

[8] B. C. Sarker, M. Hara, and M. Uemura, "Proline synthesis, physiological responses and biomass yield of eggplants during and after repetitive soil moisture stress," Scientia Horticulturae, vol. 103, no. 4, pp. 387-402, 2005.

[9] M. P. Singh, U. N. Pandey, R. K. Lal, and G. S. Chaturvedi, "Response of Brassica species to different irrigation regimes," Indian Journal of Plant Physiology, vol. 7, no. 1, pp. 66-69, 2002.

[10] F. Kimura, A. Kitoh, A. Sumi, J. Asanuma, and A. Yatagai, Downscaling of the Global Warming Projections to Turkey. The Final Report of ICCAP, Vol. 10, ICCAP Publication, Istanbul, Turkey, 2007.

[11] P. O. Boamah, J. D. Owusu-Sekyere, L. K. Sam-Amoah, and B. Anderson, "Effects of irrigation interval on chlorophyll fluorescence of tomatoes under sprinkler," Asian Journal of Agricultural Research, vol. 5, no. 1, pp. 83-89, 2011.

[12] O. A. Khadas, Effect of Different Irrigation Levels on Growth and Yield of Strawberry under Silver Black Mulch, Ph.D. dissertation, College of Agricultural Engineering and Technology, Dr. BSKKV, Dapoli, India, 2014.

[13] R. R. Sharma, Growing Strawberries, International Book Distributing Co., Lucknow, India, 2002.

[14] S. Kumar and P. Dey, "Effect of different mulches and irrigation methods on root growth, nutrient uptake, water use efficiency and yield of strawberry," Scientia Horticulturae, vol. 127, no. 3, pp. 318-324, 2011.

[15] A. Angrej and G. S. Gaur, "Effect of mulching on growth, fruit yield and quality of strawberry (Fragaria $\times$ ananassa Duch.)," Asian Journal of Horticulture, vol. 2, no. 1, pp. 149-151, 2007.

[16] B. K. Singh and K. S. Yadav, "Response of mulching on strawberry under field condition," Journal of Bio Innovation, vol. 6, no. 5, pp. 761-767, 2017.

[17] S. Pandey, J. Singh, and I. B. Maurya, "Effect of black polythene mulch on growth and yield of winter dawn strawberry (Fragaria $\times$ ananassa) by improving root zone temperature,"
Indian Journal of Agricultural Sciences, vol. 85, no. 9, pp. 1219-1222, 2015.

[18] M. V. S. Coelho, F. R. Palma, and A. C. Café-Filho, "Management of strawberry anthracnose by choice of irrigation system, mulching material and host resistance," International Journal of Pest Management, vol. 54, no. 4, pp. 347-354, 2008.

[19] A. K. Singh and S. Kamal, "Effect of black plastic mulch on soil temperature and tomato yield in mid hills of Garhwal Himalayas," Journal of Horticulture and Forestry, vol. 4, no. 4, pp. 77-79, 2012.

[20] P. Bakshi, D. J. Bhat, V. K. Wali, A. Sharma, and M. Iqbal, "Growth, yield and quality of strawberry (Fragaria $\times$ ananassa Duch.) cv. Chandler as influenced by various mulching materials," African Journal of Agricultural Research, vol. 9, no. 7, pp. 701-706, 2014.

[21] S. Shahid, "Spatial and temporal characteristics of droughts in the western part of Bangladesh," Hydrological Processes, vol. 22, no. 13, pp. 2235-2247, 2008.

[22] A. M. Michael, Irrigation: Theory and Practice, Vikas Publishing House Pvt. Ltd., New Delhi, India, 1978.

[23] M. S. Tariq, A. Bano, and K. M. Qureshi, "Response of strawberry (Frageria annanasa) cv. Chandler to different mulching materials," Science, Technology and Development, vol. 35, no. 3, pp. 117-122, 2016.

[24] J. A. Swenson, S. A. Walters, and S. K. Chong, "Influence of tillage and mulching systems on soil water and tomato fruit yield and quality," Journal of Vegetable Crop Production, vol. 10, no. 1, pp. 81-95, 2004.

[25] N. K. Headu and M. Kumar, "Effect of different mulches on yield, plant height, nitrogen uptake, weed control, soil moisture and economics of tomato cultivation," Progressive Horticulture, vol. 34, no. 2, pp. 208-210, 2002.

[26] J. C. Diaz-Perez, D. Granberry, D. Bertrand, and D. Giddings, "Tomato plant growth during establishment as affected by root zone temperature under colored mulches," in Proceedings of the XXVI International Horticultural Congress: Issues and Advances in Transplant Production and Stand Establishment Research, vol. 631, pp. 119-124, Toronto, ON, USA, August 2002.

[27] S. Kumar and P. Dey, "Influence of soil hydrothermal environment, irrigation regime, and different mulches on the growth and fruit quality of strawberry (Fragaria $\times$ ananassaL.) plants in a sub-temperate climate," Journal of Horticultural Science and Biotechnology, vol. 87, no. 4, pp. 374-380, 2012.

[28] M. A. Soliman, H. A. Abd El-Aal, M. A. Ramadan, and N. N. Elhefnawy, "Growth, fruit yield and quality of three strawberry cultivars as affected by mulch type and low tunnel," Alexandria Science Exchange Journal, vol. 36, no. 4, pp. 402-414, 2015.

[29] R. Kumar, V. Tandon, and M. M. Mir, "Impact of different mulching material on growth, yield and quality of strawberry (Fragaria $\times$ ananassa Duch.)," Progressive Horticulture, vol. 44, no. 2, pp. 234-236, 2012.

[30] S. Pandey, G. S. Tewari, J. Singh, D. Rajpurohit, and G. Kumar, "Efficacy of mulches on soil modifications, growth, production and quality of strawberry (Fragaria $\times$ ananassa Duch.)," International Journal of Science and Nature, vol. 7, no. 4, pp. 813-820, 2016.

[31] P. Kaur and A. Kaur, "Effect of various mulches on the growth and yield of strawberry cv. Chandler under sub-tropical conditions of Punjab," International Journal of Recent Trends in Science and Technology, vol. 25, no. 1, pp. 21-25, 2017.

[32] T. Yaghi, A. Arslan, and F. Naoum, "Cucumber (Cucumis sativus, L.) water use efficiency (WUE) under plastic mulch and 
drip irrigation," Agricultural Water Management, vol. 128, pp. 149-157, 2013.

[33] A. I. Saeid and G. H. Mohammed, "The Effect of color plastic mulches on growth, yield and quality of two hybrids of summer squash (cucurbita pepo 1.)," Science Journal of University of Zakho, vol. 3, no. 1, pp. 113-118, 2015.

[34] L. M. F. Castaneda, L. E. C. Antunes, N. C. Ristow, and S. Carpenedo, "Utilization of different mulching types in strawberry production," in Proceedings of the VI International Strawberry Symposium, vol. 842, pp. 111-113, Huelva, Spain, March 2008.

[35] R. Kher, J. A. Baba, and P. Bakshi, "Influence of planting time and mulching material on growth and fruit yield of strawberry cv. Chandler," Indian Journal of Horticulture, vol. 67, pp. 441-444, 2010.

[36] B. Z. Yuan, J. Sun, and S. Nishiyama, "Effect of drip irrigation on strawberry growth and yield inside a plastic greenhouse," Biosystems Engineering, vol. 87, no. 2, pp. 237-245, 2004.

[37] I. Akhtar and A. Rab, "Effect of irrigation intervals on the quality and storage performance of strawberry fruit," Journal of Animal and Plant Sciences, vol. 25, no. 3, pp. 669-678, 2015.

[38] F. Liu, S. Savić, C. R. Jensen et al., "Water relations and yield of lysimeter-grown strawberries under limited irrigation," Scientia Horticulturae, vol. 111, no. 2, pp. 128-132, 2007.

[39] V. K. Sharma and A. K. Goel, "Effect of mulching and nitrogen on growth and yield of strawberry," International Journal of Science, Environment and Technology, vol. 6, no. 3, pp. 2074-2079, 2017.

[40] A. A. Shokouhian and A. Asghari, "Study the effect of mulch on yield of some strawberry cultivars in Ardabil condition," in Proceedings of the International Conference on Agriculture, Ecology and Biological Engineering, Antalya, Turkey, September 2015. 


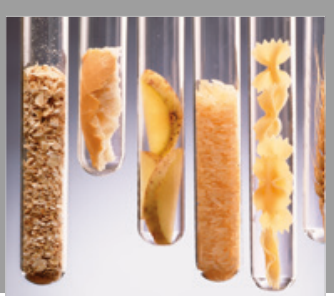

International Journal of Food Science

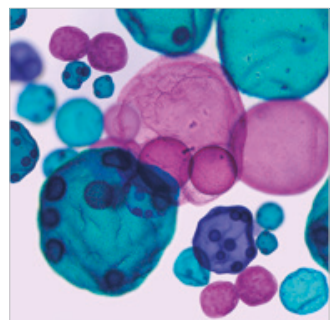

International Journal of Microbiology
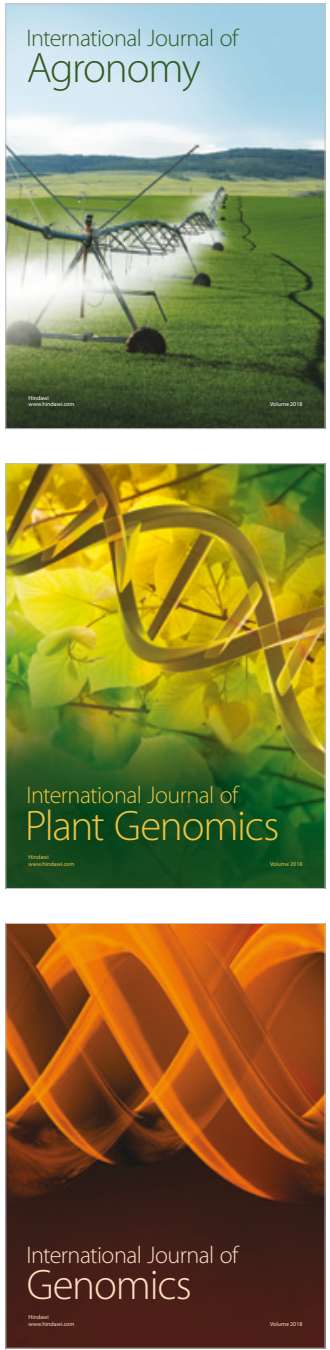

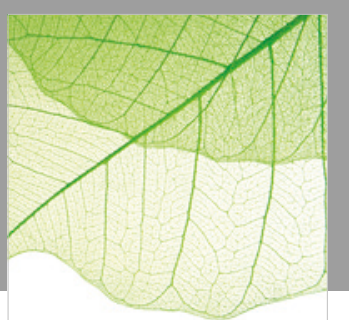

Journal of Botany
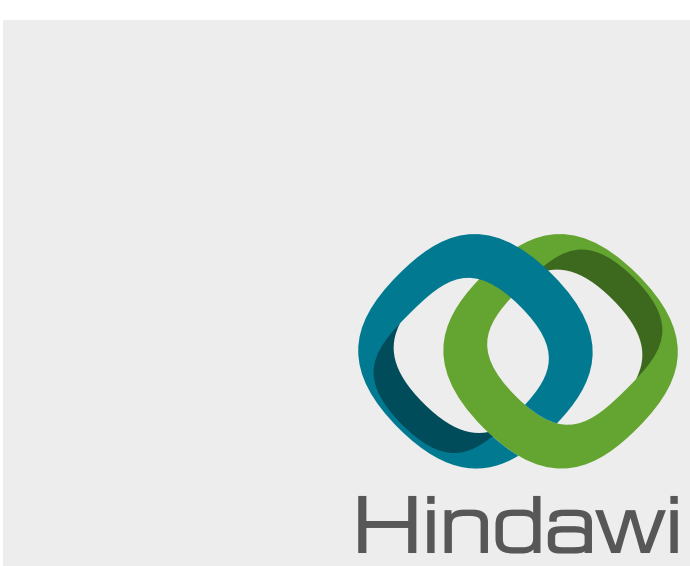

Submit your manuscripts at

www.hindawi.com
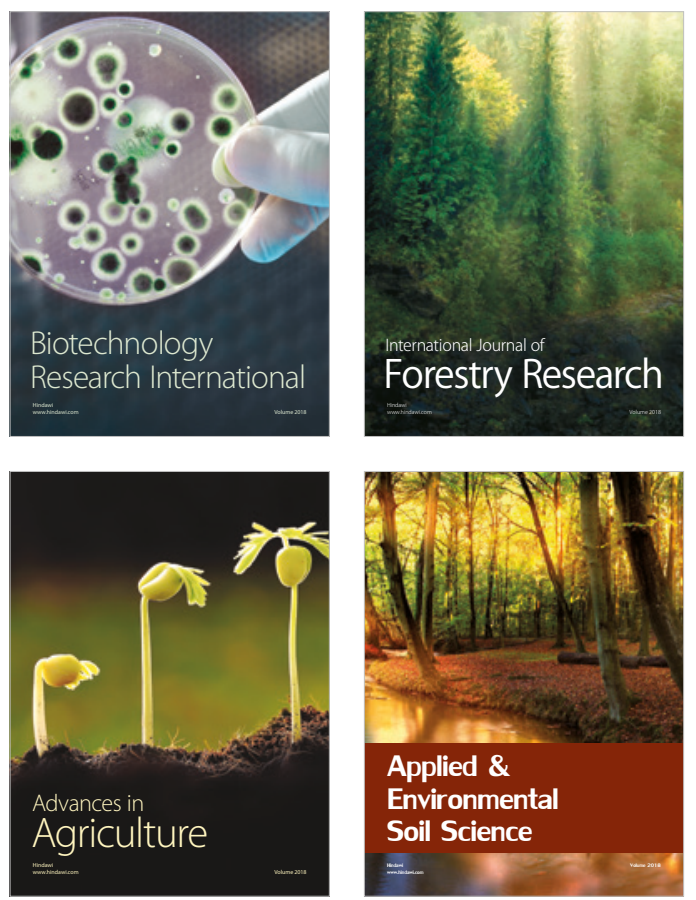

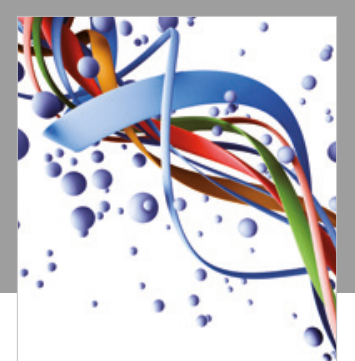

Scientifica

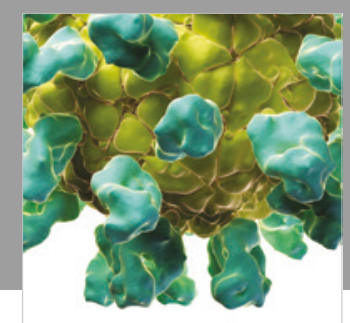

Veterinary Medicine International

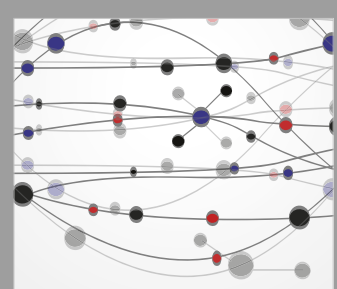

The Scientific World Journal
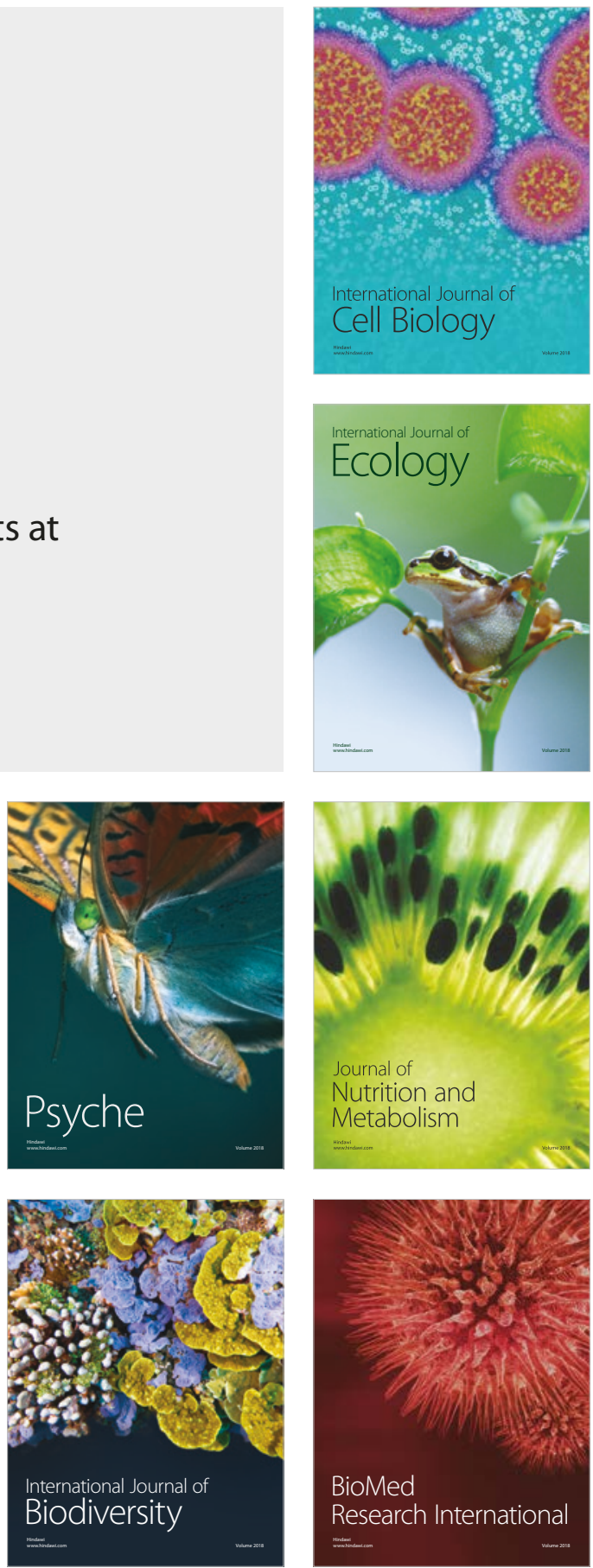